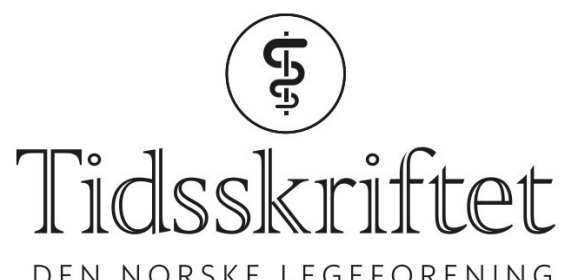

DEN NORSKE LEGEFORENING

\title{
Retterstøl og medarbeidere svarer
}

KOMMENTAR

\section{KJETIL RETTERST ØL}

E-post: kjetil.retterstol@medisin.uio.no

Kjetil Retterstøl er professor og overlege ved Universitetet i Oslo og Oslo universitetssykehus. Kjetil Retterstøl oppgir følgende interessekonflikter: Han har mottatt foredragshonorar fra Amgen, Akcea, Den norske legeforening, Sanofi, Takeda, Chiesi, Bayer, MSD og Sunovion og timehonorar fra MedXplore og Helsedirektoratet.

\section{JOHN MUNKHAUGEN}

John Munkhaugen oppgir følgende interessekonflikter: Han har mottatt foredragshonorar fra Sanofi, Amgen og Bayer.

\section{CHARLOTTE BJÖRK IGUL}

Charlotte Björk Ingul oppgir følgende interessekonflikter: Hun har mottatt honorar fra Bayer.

\section{JOSTEIN GRIMSMO}

Jostein Grimsmo oppgir følgende interessekonflikter: Han har mottatt foredragshonorar fra Bayer.

\section{ANNE KASK}

Anne Kask oppgir følgende interessekonflikter: Hun har mottatt foredragshonorar fra Bayer.

\section{HENRIK SCHIRMER}

Henrik Schirmer oppgir følgende interessekonflikter: Han har mottatt foredragshonorar fra MSD, Astra Zeneca, Sanofi og forskningsstøtte fra Novartis og Astra Zeneca.

\section{ANNE GRETE SEMB}

Anne Grete Semb oppgir følgende interessekonflikter: Hun har mottatt foredragshonorar fra Merck/Schering-Plough, BMS, UCB, Pfizer/Wyeth, Novartis, Bayer, AbbVie og Lilly og forskningsstøtte fra Lilly.

\section{ERIK EKKER SOLBERG}

Erik Ekker Solberg oppgir følgende interessekonflikter: Han har mottatt foredragshonorar fra Sanofi.

Takk til fastlege Fretland for hans innlegg og interesse for temaet. Vi lytter til hans argumenter, men vil samtidig få understreke at dokumentasjonen på LDL kolesterol anbefalingen i vår artikkel er grade 1 , level A, dvs. den sterkeste og best dokumenterte anbefalingen.

Bivirkningene av statiner er i nylig vist å være mer sjelden enn tidligere antatt $(1,2)$. Derimot er noceboeffekten av å forvente bivirkninger helt åpenbar (3). Studien fra NORCOR gruppen, som refereres i vårt innlegg, viser at målnivået $<1,4 \mathrm{mmol} / \mathrm{L}$ for LDL kolesterol er 
oppnåelig hos om lag halvparten av koronarpasientene. Dette forutsetter at man bruker tid på å forklare de gunstige statineffektene, spør om medikamentetterlevelse og undersøker sammenhengen mellom bivirkninger og tablettinntak grundig. Vi kan aktivt forme den virkeligheten vi lever i. Studien til Woods dokumenterte at dette også gjelder for pasienter som ble oppfattet som statinintolerante, hvor 50 \% begynte å ta statiner igjen etter å ha sett at bivirkningene ikke var knyttet til om de tok aktivt legemiddel eller placebo. Det er antatt at opp mot $90 \%$ av dem som ikke tåler statiner, kan bruke det ved et nytt forsøk eller skifte av preparat (4). Vi har nå anledning til å øke ambisjonsnivået i sekundærpreventivt arbeid for de med for høyt kolesterol, selv om vi ikke vil lykkes med å nå behandlingsmålet for alle.

At ESC er knyttet finansielt mot farmasien, og at slike anbefalinger derfor ikke er troverdige, er vi ikke enige i. Er det noen institusjon som virkelig har sørget for fremdrift i europeisk og norsk kardiologi så er det ESC, et eksempel på at internasjonalt samarbeid lønner seg. Det meste av ESCs arbeid er basert på frivillighet. ESC har strenge etiske retningslinjer. For å sikre transparens, er det krav om årlig oppdatering av eventuelt kontakt med legemiddelindustrien som publiseres sammen med retningslinjene. Alle kolleger kan med hell benyttes seg av ESCs mange kurstilbud (escardio.org). Vår faglige vurdering er at retningslinjene fra ESC også bør følges i Norge.

\section{LITTERATUR:}

1. Wood FA, Howard JP, Finegold JA et al. N-of-1 Trial of a Statin, Placebo, or No Treatment to Assess Side Effects. N Engl J Med 2020; 383: 2182-4. [PubMed][CrossRef]

2. Kristiansen O, Vethe NT, Peersen K et al. Effect of atorvastatin on muscle symptoms in coronary heart disease patients with self-perceived statin muscle side-effects: a randomized, double blinded crossover trial. Eur Heart J Cardiovasc Pharmacother 2020; 4: pvaao76. [PubMed][CrossRef]

3. Gupta A, Thompson D, Whitehouse A et al. Adverse events associated with unblinded, but not with blinded, statin therapy in the Anglo-Scandinavian Cardiac Outcomes Trial-Lipid-Lowering Arm (ASCOT-LLA): a randomised double-blind placebo-controlled trial and its non-randomised non-blind extension phase. Lancet 2017;389: 2473-81. [PubMed][CrossRef]

4. Stroes ES, Thompson PD, Corsini A et al. Statin-associated muscle symptoms: impact on statin therapy-European Atherosclerosis Society Consensus Panel Statement on Assessment, Aetiology and Management. Eur Heart J 2015; 36:1012-22. [PubMed][CrossRef]

Publisert: 8. mars 2021. Tidsskr Nor Legeforen. DOI: 10.4045/tidsskr.21.0122

(C) Tidsskrift for Den norske legeforening 2020. Lastet ned fra tidsskriftet.no 